\title{
Differential effects of a post-anthesis fertilizer regimen on the wheat flour proteome determined by quantitative 2-DE
}

\author{
Susan B Altenbach ${ }^{*}$, Charlene K Tanaka, William J Hurkman, Linda C Whitehand, William H Vensel and
} Frances M Dupont ${ }^{\dagger}$

\begin{abstract}
Background: Mineral nutrition during wheat grain development has large effects on wheat flour protein content and composition, which in turn affect flour quality and immunogenic potential for a commodity of great economic value. However, it has been difficult to define the precise effects of mineral nutrition on protein composition because of the complexity of the wheat flour proteome. Recent improvements in the identification of flour proteins by tandem mass spectrometry (MS/MS) and the availability of a comprehensive proteome map of flour from the US wheat Butte 86 now make it possible to document changes in the proportions of individual flour proteins that result from the application of mineral nutrition.

Results: Plants of Triticum aestivum 'Butte 86' were grown with or without post-anthesis fertilization (PAF) and quantitative 2-dimensional gel electrophoresis (2-DE) was used to analyze protein composition of the resulting flour. Significant changes in the proportions of 54 unique proteins were observed as a result of the treatment. Most omegagliadins, high molecular weight glutenin subunits (HMW-GS) and serpins as well as some alpha-gliadins increased in proportion with PAF. In contrast, alpha-amylase/protease inhibitors, farinins, purinins and puroindolines decreased in proportion. Decreases were also observed in several low molecular weight glutenin subunits (LMW-GS), globulins, defense proteins and enzymes. The ratio of HMW-GS to LMW-GS in the flour increased from 0.61 to 0.95 and the ratio of gliadins to glutenins increased from 1.02 to 1.30 with PAF. Because flour protein content doubled with PAF from 7 to $14 \%$, most protein types actually increased in absolute amount ( $\mu \mathrm{g} / \mathrm{mg}$ flour protein). Data further suggest that flour proteins change with PAF according to their content of sulfur-containing amino acids Cys + Met.

Conclusions: A 2-DE approach revealed changes in the wheat flour proteome due to PAF that are important for flour quality and immunogenic potential. The work forms a baseline for further studies of the effects of environmental variables on flour protein composition and provides clues about the regulation of specific flour protein genes. The study also is important for identifying targets for breeding programs and biotechnology efforts aimed at improving flour quality.
\end{abstract}

Keywords: gliadins, glutenins, gluten proteins, nitrogen, sulfur

\section{Background}

Each year wheat farmers make strategic decisions about the amount and timing of fertilizer applications that influence yield, grain quality, and economic returns for this major world crop. Such decisions may also impact

\footnotetext{
* Correspondence: susan.altenbach@ars.usda.gov

† Contributed equally

United States Department of Agriculture, Agricultural Research Service, Western Regional Research Center, 800 Buchanan Street, Albany, CA 94710
}

local water and air quality. One well-documented effect of fertilization with nitrogen $(\mathrm{N})$ is the increase in protein content. However, this depends in a complex way upon genotype, environment, timing and type of $\mathrm{N}$ application [1-7]. There is a strong inverse correlation between grain protein content and yield and early applications of nitrogen may increase plant growth and yield rather than grain protein [8-10]. In contrast, application of fertilizer at heading or anthesis under conditions of

\section{Biomed Central}


adequate soil moisture may be more effective in producing high yields of grain with high protein content $[4,11]$. High protein content is desirable for many wheat products and premiums are often paid for high protein bread wheat. However, mineral nutrition also affects protein composition, which impacts functionality, nutritional value, and immunogenic potential of the flour. In order to predict the effects of fertilizer applications on protein composition and identify breeding targets for improved flour quality, it is essential to understand the precise effects of fertilizer on the wheat flour proteome [12].

Wheat flour protein composition is complex [13]. The major flour protein types are identified by their tendency to partition into different solvent fractions $[7,14]$. Typically these are the water-soluble albumins, salt-soluble globulins, acid or alcohol-soluble gliadins, and a glutenin polymer that is partially soluble in acetic acid or alcohol. The proteins in each solubility fraction are encoded by multiple similar genes located at complex homeoallelic loci that are replicated in two genomes for durum wheat (A and B) and three genomes for bread wheat (A, B, and $D)$. These proteins may differ in their functional and nutritional properties and in their ability to trigger allergies and the serious food intolerance celiac disease.

Fractionation studies showed that additional $\mathrm{N}$ was differentially partitioned into gliadins and glutenins, which increased in amount per mg of flour, compared to an albumin/globulin fraction that did not increase [15-19]. Protein fractionation followed by SDS-PAGE and RPHPLC revealed more details of this response, detecting increased proportions of HMW-GS and omega-gliadins and decreased proportions of LMW-GS and albumins/ globulins in response to added $N[12,16,18]$. Similar changes in protein proportions were observed when grain was produced under conditions of sulfur (S) deficiency [20-23]. Methods used in these analyses were not adequate to completely separate the flour proteins by type. Quantitative 2-DE also has been used to measure changes in individual flour proteins in response to mineral nutrition $[15,16,20,24,25]$. But results from most studies have been limited by the challenges involved in identifying individual proteins within the major gluten protein families by MS/MS [26,27].

A recent 2-DE MS/MS study of proteins in white flour from Butte 86, a US spring wheat cultivar, identified 157 distinct proteins in 233 spots that together comprised $93 \%$ of the flour protein [28]. The 157 proteins included five HMW-GS, 22 LMW-GS, 13 gamma-gliadins, seven omega-gliadins, 23 alpha-gliadins, three farinins, three purinins, three triticins, eight globulins, three grain-softness related proteins, 16 amylase/protease inhibitors, nine serpins, three tritins, one xylanase inhibitor, three betaamylases, 33 enzymes and five other proteins. Improved proteomics techniques and the availability of numerous gene sequences from the cultivar Butte 86 made it possible to distinguish closely related proteins within the major protein groups and link them to gene sequences [28-31]. The study also demonstrated that multiple 2-DE spots, mainly in apparent charge trains, were likely to be the products of single genes. This finding made it possible to quantify the amount of each individual protein type in the flour [28]. In this paper, the improved proteomic methods were used to measure the effects of PAF on these 157 unique proteins.

\section{Results}

\section{Analysis of flour produced with and without PAF}

The effects of PAF on grain yield and flour properties were measured for grain harvested at maturity (Table 1). Bushel weight increased by $3.3 \%$, but flour yield and moisture did not change. Flour protein content doubled from $7.0 \%$ to $14.0 \%$. Standard flour quality measurements such as mixing time and mixing tolerance, did not change significantly, but loaf volume increased by $59 \%$. PAF had little effect on flour carbon (C) content. However, $\mathrm{N}$ and $\mathrm{S}$ contents increased significantly and the ratio of $\mathrm{N}: \mathrm{S}$ increased from 11 to 15 . The $\mathrm{S}$ content of flour with and without PAF was $>0.1 \%$, indicating that $\mathrm{S}$ was not deficient in our experiment. As reported previously, the treatment with PAF had little effect on the duration of grain fill or grain size (data not shown) $[1,15]$.

\section{2-DE protein spots that change in volume with PAF}

Total protein was extracted from white flour from grain produced with and without PAF and analyzed by quantitative 2-DE (Figure 1). Gel patterns among biological

Table 1 Effect of PAF on grain yield, flour properties and CNS composition

\begin{tabular}{lccc}
\hline & - PAF $^{1}$ & + PAF $^{1}$ & \% Change $^{2}$ \\
\hline Bushel Weight (kg) & $61.0+/-0.3$ & $63.0+/-0.4$ & $3.3^{*}$ \\
Flour Yield (\% dry weight) & $67.5+/-1.2$ & $68.8+/-0.6$ & 1.9 \\
Flour Moisture (\%) & $13.8+/-0.0$ & $14.2+/-0.2$ & 2.9 \\
Flour Protein (\%) & $7.0+/-0.4$ & $14.0+/-0.9$ & $100.0^{*}$ \\
Mix Time (min) & $2.8+/-0.6$ & $2.2+/-0.3$ & -21.4 \\
Mix Tolerance 3,4 & $2.3+/-0.6$ & $3.7+/-0.6$ & 60.9 \\
Loaf Volume (ml) & $51.7+/-1.5$ & $82.0+/-3.5$ & $58.6^{*}$ \\
\% C & $39.6+/-0.1$ & $40.1+/-0.1$ & 1.3 \\
$\%$ N & $1.27+/-0.06$ & $2.50+/-0.15$ & $96.9^{*}$ \\
\% S & $0.12+/-0.00$ & $0.17+/-0.01$ & $41.7^{*}$ \\
N:S & $10.6+/-0.03$ & $14.7+/-0.04$ & $38.7^{*}$ \\
\hline
\end{tabular}

${ }^{1}$ Mean and standard deviation from flour samples from three biological replicates.

$2 *$ indicates that change was significant, $\mathrm{p}<0.02$.

${ }^{3}$ Determined using $10 \mathrm{~g}$ flour samples.

${ }^{4}$ Recorded on a 1-4 scale with 4 having the greatest tolerance. 


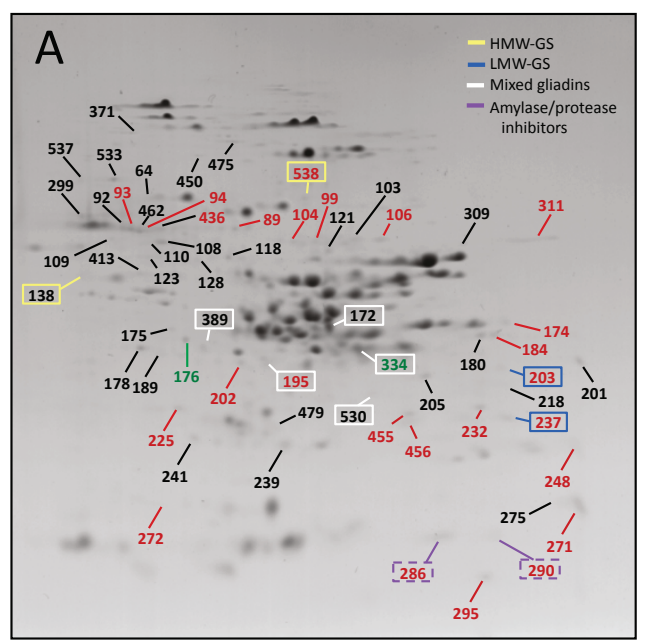

\section{HMW-GS}

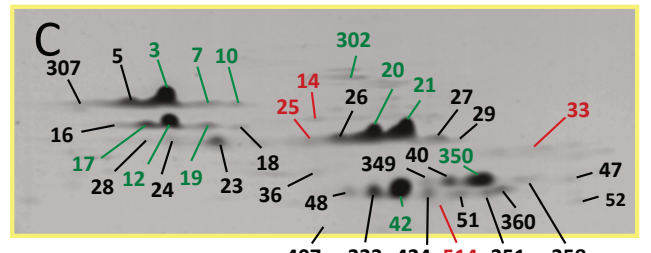

\section{Alpha-gliadins}

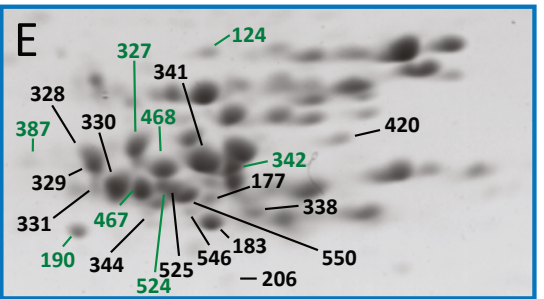

\section{LMW-GS}

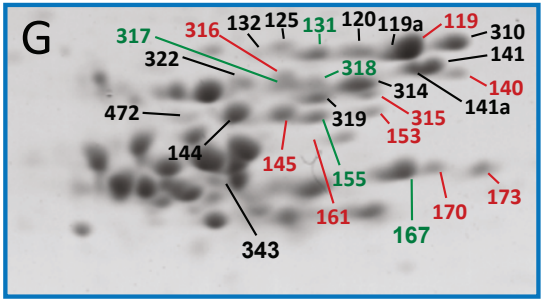

\section{Farinins and purinins}

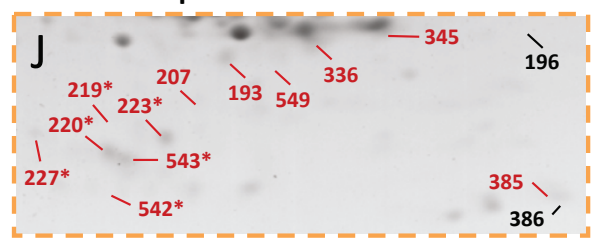

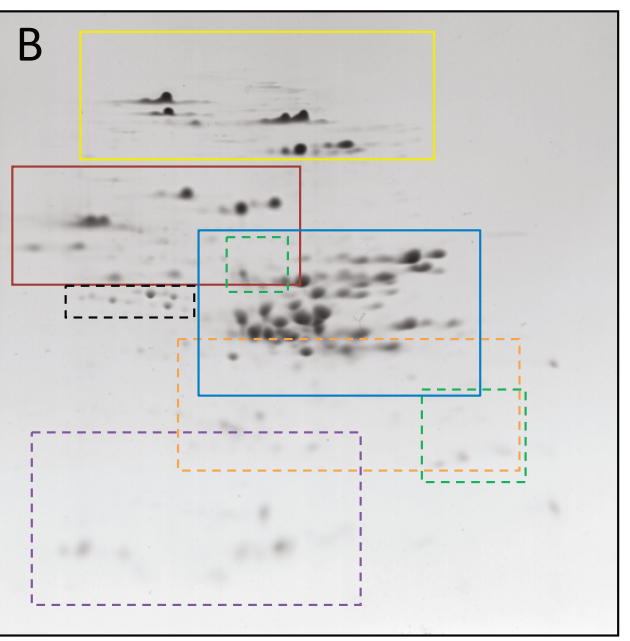

Omega-gliadins

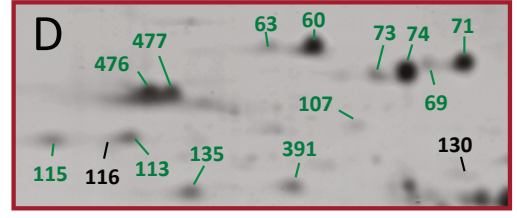

Gamma-gliadins

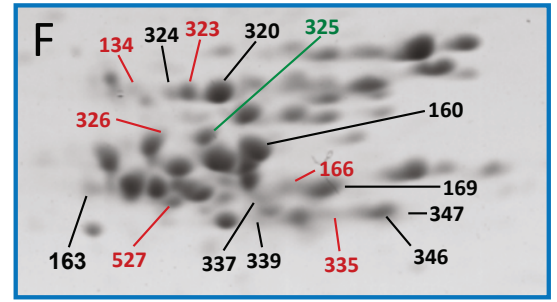

Serpins

Triticins

$\mathrm{H}$

la

$\mathrm{Ib}$
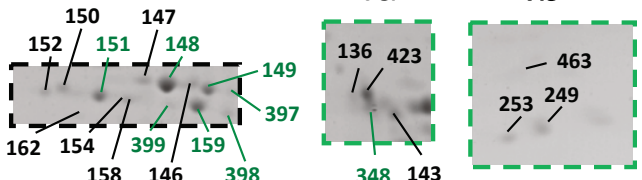

\section{Amylase/protease inhibitors}

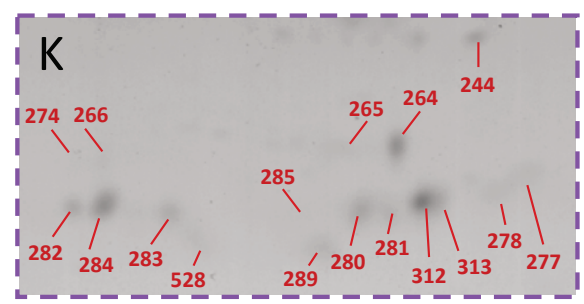

Figure 1 Effect of post-anthesis fertilizer (PAF) on accumulation levels of individual wheat flour proteins. Flour proteins from plants grown without (A) or with (B) PAF were analyzed by 2-DE. Boxes in B indicate protein classes that are depicted in panels C-K. The spots indicated in panel A fall outside the perimeters of the selected areas in panel B. The green and red numbers indicate spots that significantly increased or decreased, respectively, and the black numbers indicate spots that did not change with PAF. Spots containing the large subunits of triticin are indicated in panels la and the small subunits in $\mathrm{lb}$. Asterisks in panel $\mathrm{J}$ designate spots containing purinins. Protein sequences associated with spots that increased or decreased significantly are listed in Tables 2 and 3 . The identities of the proteins that did not change significantly are listed in Additional file 1. 
replicates and among treatments were highly reproducible. The average spot volume (SV) was determined for 373 spots from each treatment (Additional file 1). These accounted for $96.9 \%$ of total SV for the -PAF treatment and $97.7 \%$ of total SV for the +PAF treatment. Proteins in 231 spots were identified by tandem mass spectrometry (MS/MS) in the previous study of Dupont et al. [28]. Identified spots accounted for $89.7 \%$ of total SV for the -PAF treatment and $92.8 \%$ of total SV for the +PAF treatment. Of the 373 spots quantified by 2-DE, 155 spots had significant $(\mathrm{p}<0.02)$ differences in SV under the two fertilizer regimens (Additional file 1). These spots accounted for approximately $50 \%$ of the total SV under both treatments. Fifty-one spots increased with PAF and 104 spots decreased with PAF (Additional file 1).

Among the spots that increased with PAF were 13 spots identified as omega-gliadins, 11 spots identified as HMW-GS, eight spots identified as alpha-gliadins, seven spots identified as serpins, five spots identified as LMWGS, and one spot identified as gamma-gliadin (Figure 1, Table 2). Additional spots that increased were one that contained a mixture of alpha- and gamma-gliadins, one identified as triticin and one identified as malate dehydrogenase. Spots that increased with PAF were associated with 27 distinct protein sequences. Three other minor spots also increased with PAF but had volumes

Table 2 2-DE spots that increased significantly with PAF

\begin{tabular}{|c|c|}
\hline Spot Number & Protein Sequence $^{1}$ \\
\hline 60 & Omega-gliadin Gli-B3 TC11_288652² \\
\hline 63 & Omega-gliadin Gli-B3 TC11_288652² \\
\hline 71 & Omega-gliadin Gli-B3 TC11_288652² \\
\hline 74 & Omega-gliadin Gl-iB3 TC11_288652² \\
\hline 69 & Omega-gliadin Gli-B33 \\
\hline 73 & Omega-gliadin Gli-B333 \\
\hline 107 & Omega-gliadin Cys type TC_262770² \\
\hline 113 & Omega-gliadin Cys type TC_262770 \\
\hline 115 & Omega-gliadin Cys type TC_262770 ${ }^{4}$ \\
\hline 135 & Omega-gliadin Gli-A3 Bu-D5² \\
\hline 391 & Omega-gliadin Gli-A3 Bu-D5 5 \\
\hline 476 & Omega-gliadin Gli-D333 \\
\hline 477 & Omega-gliadin Gli-D3 [GenBank:AAT74547] ${ }^{5}$ \\
\hline 12 & HMW-GS Ax2* [GenBank:AAB02788] ${ }^{2}$ \\
\hline 17 & HMW-GS Ax2* [GenBank:AAB02788] ${ }^{2}$ \\
\hline 19 & HMW-GS Ax2* [GenBank:AAB02788] ${ }^{2}$ \\
\hline 20 & HMW-GS Bx7 [GenBank:CAA32115]² \\
\hline 21 & HMW-GS Bx7 [GenBank:CAA32115]² \\
\hline 302 & HMW-GS Bx7 [GenBank:CAA32115]² \\
\hline 350 & HMW-GS 1By9 [GenBank:CAA43361]² \\
\hline 3 & HMW-GS Dx5 [GenBank:ABG68042]² \\
\hline 7 & HMW-GS Dx5 [GenBank:ABG68042]² \\
\hline 10 & HMW-GS Dx5 [GenBank:ABG68042] ${ }^{2}$ \\
\hline
\end{tabular}

Table 2 2-DE spots that increased significantly with PAF (Continued)

\begin{tabular}{|c|c|}
\hline 42 & HMWGS Dy10 [GenBank:P10387] \\
\hline 342 & Alpha-gliadin Bu-1,6 \\
\hline 468 & Alpha-gliadin Bu-3 $3^{5,6}$ \\
\hline 467 & Alpha-gliadin Bu-4, \\
\hline 327 & Alpha-gliadin Bu- $11^{5}$ \\
\hline 387 & Alpha-gliadin Bu-12 $2^{5}$ \\
\hline 524 & Alpha-gliadin Bu-12 ${ }^{5}$ \\
\hline 190 & Alpha-gliadin Bu-14 \\
\hline 124 & Alpha-gliadin Bu-BQ807130²,6 \\
\hline 148 & Serpin $\mathrm{Bu}-1^{2}$ \\
\hline 149 & Serpin $\mathrm{Bu}-2^{5}$ \\
\hline 397 & Serpin $\mathrm{Bu}-2^{2}$ \\
\hline 398 & Serpin $\mathrm{Bu}-3^{2}$ \\
\hline 399 & Serpin $\mathrm{Bu}-3^{2}$ \\
\hline 159 & Serpin Bu-4 4,6 \\
\hline 151 & Serpin Bu- $5^{2}$ \\
\hline 167 & LMW-GS Bu-1 $1^{5}$ \\
\hline 131 & LMW-GS Bu-3² \\
\hline 317 & LMW-GS Bu-2/13 $3^{4}$ \\
\hline 318 & LMW-GS Bu-2/13 \\
\hline 155 & LMW-GS Bu-18 \\
\hline 325 & Gamma-gliadin Bu-1or Bu-8 $8^{5,7}$ \\
\hline 334 & Gliadin, mixed spot $^{8}$ \\
\hline 348 & Triticin TC11_285558 5 \\
\hline 176 & Malate dehydrogenase [GenBank:AAT64932] \\
\hline
\end{tabular}

${ }^{1}$ Identifications are from Dupont et al. [28]

${ }^{2}$ MS/MS analysis in [28] indicated that spot contained only one protein.

${ }^{3}$ No peptides identified by MS/MS in [28]. Spot identified in [43].

${ }^{4}$ Predominant protein identified by MS/MS in [28]. Analysis indicated that spot also contained other proteins from the same class.

${ }^{5}$ Predominant protein identified by MS/MS in [28]. Analysis indicated that spot also contained proteins from a different class.

${ }^{6}$ Predominant protein sequence identified in only one spot.

${ }^{7}$ MS/MS data in [28] was not sufficient to discriminate among proteins.

${ }^{8}$ More than one protein was identified in spot in [28], but no one protein was predominant.

less than 0.1 and were not identified in Dupont et al. [28] (Additional file 1).

Among the spots that decreased significantly with PAF were 19 identified as alpha-amylase/protease inhibitors, 11 as LMW-GS, six as gamma-gliadins, six as farinins, six as purinins, five minor spots identified as globulins, five minor spots identified as HMW-GS, two spots identified as beta-amylase, two spots as chitinase and two as puroindoline (Figure 1, Table 3). Single spots identified as the large subunit of ADP glucose pyrophosphorylase, lipid transfer protein (LTP), thaumatin-like protein, triose phosphate isomerase, elongation factor EF1A, and glucose and ribitol dehydrogenase as well as one spot that contained a mixture of gliadins also decreased in SV with PAF. Spots that decreased with PAF were associated with 50 distinct protein sequences. Thirty-three 
Table 3 Individual 2-DE spots that decreased significantly with PAF

\begin{tabular}{|c|c|}
\hline $\begin{array}{l}\text { Spot } \\
\text { Number }\end{array}$ & Protein Sequence $^{1}$ \\
\hline 289 & Alpha-amylase inhibitor WMAI [PRF:223520] ${ }^{2}$ \\
\hline 528 & Alpha-amylase inhibitor WMAI [PRF:223520] ${ }^{2}$ \\
\hline 283 & Alpha-amylase inhibitor WDAI TC11_338524 3 3,4 \\
\hline 286 & Alpha-amylase inhibitor WDAI [GenBank:AAV91972] \\
\hline 312 & Alpha-amylase inhibitor WDAI [SwissProt:P01085] ${ }^{4,5}$ \\
\hline 313 & Alpha-amylase inhibitor WTAI-CM1 TC11_340510 ${ }^{4,5}$ \\
\hline 280 & Alpha-amylase inhibitor WTAI-CM2 [SwissProt:P16851] ${ }^{3}$ \\
\hline 285 & Alpha-amylase inhibitor WTAI-CM2 [SwissProt:P16851] ${ }^{3}$ \\
\hline 264 & Alpha-amylase inhibitor WTAI-CM3 [SwissProt:P17314] ${ }^{3}$ \\
\hline 265 & Alpha-amylase inhibitor WTAI-CM3 [SwissProt:P17314] ${ }^{3}$ \\
\hline 266 & Alpha-amylase inhibitor WTAI-CM16 [SwissProt:P16159] ${ }^{2}$ \\
\hline 284 & Alpha-amylase inhibitor WTAI-CM16 [SwissProt:P16159] ${ }^{2}$ \\
\hline 274 & Alpha-amylase inhibitor WTAI-CM17 [GenBank:CAA42453] \\
\hline 282 & Alpha-amylase inhibitor WTAI-CM17 [GenBank:CAA42453] \\
\hline 244 & $\begin{array}{l}\text { Alpha-amylase/subtilisin inhibitor WASI [SwissProt:P16347] } \\
2,4\end{array}$ \\
\hline 281 & Protease inhibitor CMx1/CM×3 TC11_309398 \\
\hline 290 & Protease inhibitor CMx1/CM×3 TC11_308146 \\
\hline 277 & Chymotrypsin inhibitor WCI [GenBank:CAD19440] ${ }^{2,4}$ \\
\hline 278 & Chymotrypsin inhibitor WCl, mixed spot ${ }^{6}$ \\
\hline 170 & LMW-GS Bu-1 ${ }^{5}$ \\
\hline 119 & LMW-GS Bu-32 \\
\hline 161 & LMW-GS Bu- $3^{5}$ \\
\hline 237 & LMW-GS Bu-32 \\
\hline 316 & LMW-GS Bu-3 $3^{5}$ \\
\hline 140 & LMW-GS Bu-4² \\
\hline 173 & LMW-GS Bu- $6^{4,5}$ \\
\hline 145 & LMW-GS Bu- $7^{3}$ \\
\hline 203 & LMW-GS Bu- $11^{5}$ \\
\hline 315 & LMW-GS Bu- $11^{3}$ \\
\hline 153 & LMW-GS Bu-18² \\
\hline 326 & Gamma-gliadin Bu-1,5 \\
\hline 166 & Gamma-gliadin Bu4 ${ }^{5}$ \\
\hline 134 & Gamma-gliadin Bu-5 $5^{5}$ \\
\hline 323 & Gamma-gliadin Bu-5 $5^{5}$ \\
\hline 335 & Gamma-gliadin Bu-65 \\
\hline 527 & Gamma-gliadin Bu-1 $11^{5}$ \\
\hline 385 & Farinin $\mathrm{Bu}-1^{2}$ \\
\hline 193 & Farinin $\mathrm{Bu}-2^{5}$ \\
\hline 207 & Farinin $\mathrm{Bu}-2^{2}$ \\
\hline 549 & Farinin $\mathrm{Bu}-2^{2}$ \\
\hline 336 & Farinin $\mathrm{Bu}-3^{5}$ \\
\hline 345 & Farinin $\mathrm{Bu}-3^{5}$ \\
\hline 542 & Purinin $\mathrm{Bu}-1^{5}$ \\
\hline 543 & Purinin $\mathrm{Bu}-1^{5}$ \\
\hline 219 & Purinin $\mathrm{Bu}-2^{2}$ \\
\hline 223 & Purinin $\mathrm{Bu}-2^{2}$ \\
\hline 220 & Purinin $\mathrm{Bu}-3^{2}$ \\
\hline 227 & Purinin $\mathrm{Bu}-3^{2}$ \\
\hline
\end{tabular}

Table 3 Individual 2-DE spots that decreased significantly with PAF (Continued)

\begin{tabular}{|c|c|}
\hline 99 & Globulin-2 Bu-17366 2,4 \\
\hline 104 & Globulin-2 Bu-17295² \\
\hline 106 & Globulin-2 Bu-18428² \\
\hline 184 & Globulin Glo-3 TC11_305389 3 \\
\hline 272 & Globulin Glo-3 TC_234094 $4^{5}$ \\
\hline 14 & HMW-GS Dx5 [GenBank:ABG68042]² \\
\hline 538 & HMW-GS Dx5 [GenBank:ABG68042]² \\
\hline 25 & HMW-GS Bx7 [GenBank:CAA32115]² \\
\hline 33 & HMW-GS Bx7 [GenBank:CAA32115]² \\
\hline 514 & HMWGS Dy10 [GenBank:P10387]² \\
\hline 94 & Beta-amylase Bu-2 ${ }^{3}$ \\
\hline 93 & Beta-amylase Bu-3 $3^{3}$ \\
\hline 232 & Chitinase [GenBank:BAB18520] ${ }^{2,4}$ \\
\hline 455 & Chitinase [GenBank:AAX83262.1] $]^{2,4}$ \\
\hline 248 & Puroindoline-b [GenBank:AAT40244] $]^{3}$ \\
\hline 271 & Puroindoline-b [GenBank:AAT40244] ${ }^{2}$ \\
\hline 89 & $\begin{array}{l}\text { ADP glucose pyrophosphorylase, large subunit [GenBank: } \\
\text { CAD98749] }{ }^{2}\end{array}$ \\
\hline 295 & Lipid transfer protein (LTP) Bu-2, 2,4 \\
\hline 456 & Thaumatin-like protein TC11_283136 2,4 \\
\hline 225 & Triose phosphate isomerase [GenBank:CAC14917] $]^{2,4}$ \\
\hline 311 & Elongation factor EF1A [SwissProt:Q03033] $]^{2,4}$ \\
\hline 202 & Glucose and ribitol dehydrogenase RS_UWI_14903 2,4 \\
\hline 195 & Gliadin, mixed spot ${ }^{6}$ \\
\hline
\end{tabular}

${ }^{1}$ Identifications are from Dupont et al. [28].

${ }^{2}$ MS/MS analysis in Dupont et al. [28] indicated that spot contained only one protein.

${ }^{3}$ Predominant protein identified by MS/MS in Dupont et al. [28]. Analysis indicated that spot also contained other proteins from the same class.

${ }^{4}$ Predominant protein sequence identified in only one spot.

${ }^{5}$ Predominant protein identified by MS/MS in [28]. Analysis indicated that spot also contained proteins from a different class.

${ }^{6}$ More than one protein was identified in spot, but no one protein was predominant.

other spots decreased significantly in SV, but were not identified by MS/MS in Dupont et al. [28]. All but one were minor spots with volumes less than 0.1 in the absence of PAF (Additional file 1).

\section{Flour proteins that change in relative proportion with PAF}

In the Dupont et al study [28], the same protein sequence was often associated with multiple 2-DE spots that were likely the result of charge trains, minor post-translational modifications or the lack of distinguishing peptides for the products of slightly different genes. Because it is important to consider the overall response of each protein, volumes of all spots associated with the same protein sequence were summed and compared under the two treatments (Additional file 2). The combined volumes of all spots associated with each of 54 unique 
protein sequences showed significant $(\mathrm{p}<0.02)$ changes with PAF (Table 4).

Proteins in four classes generally showed significant increases (Table 4). Some of the largest and most consistent changes were found among the omega-gliadins. Combined SVs for four different omega-gliadins ranged from 0.4 to 1.9 in the absence of PAF and 1.0 to 5.1 with PAF. Increases in SV ranged from $117 \%$ for the Gli-D3 omega-gliadins to $161 \%$ for the Gli-B3 omega-gliadins. The Gli-B3 omega-gliadins are of particular interest because they have been associated with the serious food allergy wheat-dependent exercise-induced anaphylaxis (WDEIA). Omega-gliadins that contain single cysteine residues and are likely incorporated into the glutenin polymer (omega-gliadin Cys type TC_262777) also increased in SV from 0.5 to 1.2 , a $148 \%$ change. Combined spots associated with each of the five HMW-GS sequences also increased significantly in volume. SVs for individual HMW-GS types ranged from 1.5 to 3.9 in the absence of PAF and 2.3 to 5.0 with PAF (Table 4). Changes in SV ranged from a 19\% increase for Dy10 to a $54 \%$ increase for By9. Only six alpha-gliadins increased significantly. Three alpha-gliadins, $\mathrm{Bu}-1, \mathrm{Bu}-3$ and $\mathrm{Bu}-4$, contain multiple $\mathrm{T}$-cell stimulatory epitopes involved in celiac disease and are encoded at the Gli-D2 locus [30]. SVs for these alpha-gliadins ranged from 0.5 to 1.3 in the absence of PAF and 0.8 to 2.0 with PAF, with increases of $36 \%$ to $64 \%$. Bu-12 is an abundant alpha-gliadin encoded at the Gli-B2 locus that does not contain any of the major T-cell stimulatory epitopes or toxic sequences associated with celiac disease. The SV for this protein was 1.9 in the absence of PAF and 3.1 with PAF, a $61 \%$ increase. Alpha-gliadin $\mathrm{Bu}-14$ is encoded at the Gli-A2 locus and contains the p31-43 sequence associated with the activation of the innate immune system in celiac disease [28]. This protein increased in total SV from 0.8 to 1.1 , a $33 \%$ increase. Bu-BQ807130 is a minor alphagliadin that increased $53 \%$. The serpins are the fourth group of proteins that generally showed increases in combined SVs. Spots associated with five serpin sequences showed significant increases in volume and ranged from 0.04 to 0.5 in the absence of PAF and 0.04 to 0.6 with PAF. Although serpin $\mathrm{Bu}-2$ and $\mathrm{Bu}-3$ showed 126 and $189 \%$ increases, respectively, both were relatively minor components of the flour. One minor serpin also showed a $41 \%$ decrease in total SV.

Proteins in three classes generally showed consistent decreases in SV (Table 4). Proteins associated with thirteen different sequences within the alpha-amylase/protease inhibitor family showed decreases in SV that ranged from 35 to $66 \%$. SVs for these proteins ranged from 0.07 to 1.41 in the absence of PAF and 0.03 to 0.67 with PAF. The farinins and purinins also decreased consistently with PAF. SVs for the three farinins ranged from
0.36 to 1.27 in the absence of PAF and 0.25 to 0.34 with PAF while purinins ranged from 0.49 to 0.52 in the absence of PAF and 0.26 to 0.29 with PAF. Three LMWGS also showed decreases of 24 to $26 \%$ with PAF. Bu-3, encoded at the Glu-B3 locus, is the most abundant protein in Butte 86 flour with SVs of 8.0 in the absence of PAF and 6.1 with PAF. Bu-7, encoded at the Glu-D3 locus, is also a major LMW-GS with SVs of 3.3 in the absence of PAF and 2.5 with PAF. LMW-GS Bu-6, encoded at the Glu-A3 locus, is a minor LMW-GS with SVs of only 0.6 in the absence of PAF and 0.5 with PAF. In contrast to most of the other gluten proteins, only one gamma-gliadin changed significantly with PAF. Bu-1 is a minor gamma-gliadin that decreased 31\% in SV from 0.19 to 0.13 . Two globulin-2 proteins that are relatively minor flour proteins also decreased significantly. Puroindoline b decreased $51 \%$ from 0.51 to 0.25 in total SV and beta-amylase $\mathrm{Bu}-2$ decreased $37 \%$ from 0.23 to 0.15 in SV. Three defense proteins decreased, two chitinases by 57 and $62 \%$, respectively, and LTP by $70 \%$. Other proteins that decreased significantly included a thaumatinlike protein, triose phosphate isomerase, elongation factor EF1A and glucose and ribitol dehydrogenase. All had total SVs that were less than 0.2 in the absence of $\mathrm{PAF}$ and were found in single 2-DE spots.

\section{Overall effects of PAF on flour protein composition}

Table 5 summarizes the effects of PAF on the accumulation of the different classes of wheat flour proteins. The omega-gliadins by far showed the greatest response to PAF with 13 of 15 spots and four of five protein sequences showing significant increases. Omega-gliadins encoded at the Gli-A3f, Gli-B3h, and Gli-D3a loci all showed significant changes (Additional file 3). Overall, the omega-gliadins increased $144 \%$ in total SV. HMWGS increased 33\% overall with significant changes in 16 of 40 spots and all five protein sequences. Alpha-gliadins also increased $31 \%$ overall even though only eight of 22 spots and six of 13 predominant sequences showed significant changes. Only alpha-gliadins encoded at the Gli-B2 and Gli-D2 loci showed significant changes (Additional file 3). Serpins increased $37 \%$ overall although significant changes were observed in only seven of 14 spots and five of seven protein sequences. The serpins are far less abundant than the glutenins and gliadins with combined SVs of only 1.2 in the absence of PAF and 1.6 with PAF. LMW-GS showed a 15\% decrease in overall amount with 16 of 29 spots showing significant changes but only three of 11 protein sequences. When summed, only LMW-GS at the Glu-B3h and the Glu-D3a loci showed significant changes in SV with PAF (Additional file 3). Farinins, purinins, alpha-amylase/protease inhibitors and puroindolines all showed decreases overall that ranged from 45 to $63 \%$. Beta-amylases also showed a $25 \%$ 
Table 4 Unique proteins that changed significantly with PAF

\begin{tabular}{|c|c|c|c|c|c|}
\hline \multirow[b]{2}{*}{ Protein Sequence $^{1}$} & \multirow[b]{2}{*}{ \# Spots } & \multirow[b]{2}{*}{ Spot Numbers ${ }^{2}$} & \multicolumn{2}{|c|}{ Spot Volume } & \multirow[b]{2}{*}{$\%$ Change } \\
\hline & & & -PAF & +PAF & \\
\hline Omega-gliadin Gli-B3 type ${ }^{3}$ & 6 & $60^{+}, 63^{+}, 69^{+}, 71^{+}, 73^{+}, 74^{+}$ & 1.940 & 5.070 & 161.4 \\
\hline Omega-gliadin Gli-D3 type ${ }^{4}$ & 2 & $476^{+}, 477^{+}$ & 1.413 & 3.059 & 116.5 \\
\hline Omega-gliadin Bu-D5 & 2 & $135^{+}, 391^{+}$ & 0.392 & 0.985 & 151.4 \\
\hline Omega-gliadin Cys type TC_262770 & 4 & $107^{+}, 113^{+}, 115^{+}, 116$ & 0.502 & 1.248 & 148.4 \\
\hline HMW-GS Ax2* [GenBank:AAB02788] & 8 & $12^{+}, 16,17^{+}, 18,19^{+}, 23,24,28$ & 1.719 & 2.411 & 40.2 \\
\hline HMW-GS Bx7 [GenBank:CAA32115] & 8 & $20^{+}, 21^{+}, 25^{-}, 26,27,29,33^{-}, 302^{+}$ & 3.885 & 5.019 & 29.2 \\
\hline HMW-GS Dx5 [GenBank:ABG68042] & 9 & $3^{+}, 5,7^{+}, 10^{+}, 14^{-}, 36,138,307,538^{-}$ & 2.691 & 3.732 & 38.7 \\
\hline HMW-GS 1By9 [GenBank:CAA43361] & 8 & $40,47,52,358,349,350^{+}, 351,360$ & 1.478 & 2.277 & 54.0 \\
\hline HMWGS Dy10 [GenBank:P10387] & 7 & $42^{+}, 48,51,333,407,424,514^{-}$ & 3.100 & 3.675 & 18.6 \\
\hline Alpha-gliadin Bu-1 & 1 & $342^{+}$ & 0.516 & 0.845 & 63.8 \\
\hline Alpha-gliadin Bu-3 & 1 & $468^{+}$ & 1.219 & 1.658 & 36.0 \\
\hline Alpha-gliadin Bu-4 & 1 & $467^{+}$ & 1.296 & 2.006 & 54.7 \\
\hline Alpha-gliadin Bu-12 & 5 & $328,329,387^{+}, 524^{+}, 525$ & 1.903 & 3.063 & 60.9 \\
\hline Alpha-gliadin Bu-14 & 4 & $331,190^{+}, 206,546$ & 0.821 & 1.094 & 33.2 \\
\hline Alpha-gliadin Bu-BQ807130 & 1 & $124^{+}$ & 0.188 & 0.287 & 52.6 \\
\hline Serpin Bu-1 & 3 & $146,147,148^{+}$ & 0.461 & 0.599 & 30.1 \\
\hline Serpin Bu-1 or Bu-4 & 2 & 158,162 & 0.069 & 0.040 & -41.3 \\
\hline Serpin Bu-2 & 2 & $149^{+}, 397^{+}$ & 0.067 & 0.193 & 188.6 \\
\hline Serpin Bu-3 & 2 & $398^{+}, 399^{+}$ & 0.038 & 0.087 & 126.1 \\
\hline Serpin Bu-4 & 1 & $159^{+}$ & 0.146 & 0.236 & 62.2 \\
\hline Serpin Bu-5 & 2 & $151^{+}, 154$ & 0.181 & 0.268 & 48.5 \\
\hline Alpha-amylase inhibitor WMAI [PRF:223520] & 2 & $289^{-}, 528^{-}$ & 1.043 & 0.492 & -52.9 \\
\hline Alpha-amylase inhibitor WDAI TC11_338524 & 1 & $283^{-}$ & 0.357 & 0.216 & -39.6 \\
\hline Alpha-amylase inhibitor WDAl [GenBank:AAV91972] & 1 & $286^{-}$ & 0.274 & 0.115 & -57.9 \\
\hline Alpha-amylase inhibitor WDAl [SwissProt:P01085] & 1 & $312^{-}$ & 1.305 & 0.671 & -48.6 \\
\hline Alpha-amylase inhibitor WTAI-CM1 TC11_340510 & 1 & $313^{-}$ & 0.557 & 0.210 & -62.3 \\
\hline Alpha-amylase inhibitor WTAI-CM2 [Swiss-Prot:P16851] & 2 & $285^{\circ}, 280^{-}$ & 1.377 & 0.479 & -65.2 \\
\hline Alpha-amylase inhibitor WTAI-CM3 [Swiss-Prot:P17314] & 2 & $264^{-}, 265^{-}$ & 1.409 & 0.495 & -64.9 \\
\hline Alpha-amylase inhibitor WTAI-CM16 [Swiss-Prot:P16159] & 2 & $266^{\circ}, 284^{-}$ & 1.235 & 0.512 & -58.6 \\
\hline Alpha-amylase inhibitor WTAI-CM17 [Genbank:CAA42453] & 2 & $274^{-}, 282^{-}$ & 0.634 & 0.217 & -65.8 \\
\hline Alpha-amylase/subtilisin inhibitor WASI [SwissProt:P16347] & 1 & $244^{-}$ & 0.264 & 0.171 & -35.0 \\
\hline Protease inhibitor CM×1/CM×3 TC11_309398 & 1 & $281^{-}$ & 0.361 & 0.229 & -36.5 \\
\hline Protease inhibitor CMx1/CM×3 TC11_308146 & 1 & $290^{-}$ & 0.074 & 0.028 & -62.8 \\
\hline Chymotrypsin inhibitor WCI [GenBank:CAD19440] & 1 & $277^{-}$ & 0.327 & 0.116 & -64.7 \\
\hline Farinin Bu-1 & 3 & $196,385,386$ & 0.358 & 0.246 & -31.2 \\
\hline Farinin $\mathrm{Bu}-2$ & 3 & $193^{-}, 207^{-}, 549^{-}$ & 1.271 & 0.325 & -74.4 \\
\hline Farinin Bu-3 & 2 & $336,345^{-}$ & 0.815 & 0.336 & -58.7 \\
\hline Purinin Bu-1 & 2 & $542^{-}, 543^{-}$ & 0.487 & 0.294 & -39.7 \\
\hline Purinin Bu-2 & 2 & $219^{-}, 223^{-}$ & 0.524 & 0.261 & -50.2 \\
\hline Purinin Bu-3 & 2 & $220^{-}, 227^{-}$ & 0.491 & 0.270 & -45.0 \\
\hline LMW-GS Bu-3 & 9 & $119^{\circ}, 119 a, 120,131^{+}, 132,161^{\circ}, 237^{-}, 310,316^{-}$ & 8.015 & 6.062 & -24.4 \\
\hline LMW-GS Bu-6 & 1 & $173^{-}$ & 0.634 & 0.471 & -25.7 \\
\hline LMW-GS Bu-7 & 3 & $144,145^{-}, 472$ & 3.320 & 2.473 & -25.5 \\
\hline Gamma-gliadin Bu-1 & 1 & $326^{-}$ & 0.191 & 0.132 & -30.9 \\
\hline Globulin-2 Bu-18428 & 2 & 103,106 & 0.129 & 0.088 & -31.6 \\
\hline Globulin-2 Bu-17366 & 1 & 99 & 0.043 & 0.028 & -34.1 \\
\hline Chitinase [GenBank:BAB18520] & 1 & $232^{-}$ & 0.095 & 0.041 & -56.8 \\
\hline Chitinase [GenBank:AAX83262.1] & 1 & $455^{-}$ & 0.125 & 0.047 & -62.3 \\
\hline 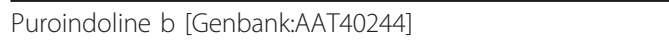 & 2 & $248^{-}, 271^{-}$ & 0.512 & 0.251 & -51.0 \\
\hline
\end{tabular}


Table 4 Unique proteins that changed significantly with PAF (Continued)

\begin{tabular}{|c|c|c|c|c|c|}
\hline Beta-amylase Bu-2 & 2 & 94,462 & 0.231 & 0.145 & -37.4 \\
\hline Lipid transfer protein (LTP) Bu-2 & 1 & $295^{-}$ & 0.117 & 0.035 & -69.8 \\
\hline Thaumatin-like protein TC11_283136 & 1 & $456^{-}$ & 0.095 & 0.049 & -48.4 \\
\hline Triose phosphate isomerase [GenBank:CAC14917] & 1 & $225^{-}$ & 0.081 & 0.046 & -42.6 \\
\hline Elongation factor EF1A [SwissProt:Q03033] & 1 & $311^{-}$ & 0.168 & 0.113 & -32.7 \\
\hline Glucose and ribitol dehydrogenase RS_UWI_14903 & 1 & $202^{-}$ & 0.117 & 0.004 & -96.6 \\
\hline
\end{tabular}

${ }^{1}$ Identifications are from Dupont et al. [28].

2 Spots that increased or decreased significantly $(p<0.02)$ are indicated with + and -, respectively.

${ }^{3}$ Includes proteins identified as TC11_288652.

${ }^{4}$ Includes protein identified as [GenBank:AAT74547].

decrease even though significant changes were observed in only two of six spots and one of three protein sequences. Other enzymes also decreased by $29 \%$ even though only six of 23 spots and four of 20 protein sequences showed significant changes.

The gluten proteins comprised a larger proportion of the total protein in flour produced with PAF. Combined SV for all gluten proteins was 68.8 in the absence of PAF and 80.6 with PAF. While the combined SV for the glutenins was similar under the two treatments, the combined SV for the gliadins increased from 32.7 to 43.0 with PAF. The ratio of HMW-GS to LMW-GS increased from 0.61 to 0.95 . The ratio of gliadins to glutenins also increased from 1.02 to 1.30 with PAF.

Relationship between response of proteins to PAF and Samino acid content

The analysis of spot volume data highlights the manner in which PAF alters the proportion of different proteins in the flour and is critical for understanding the effects of PAF on protein composition and flour quality. However, analysis of the data in terms of absolute protein amounts provides additional insight into effects of PAF on flour composition. It is important to recognize that total

Table 5 Summary of changes in protein classes with PAF

\begin{tabular}{|c|c|c|c|c|c|c|c|c|c|}
\hline & \multirow[b]{2}{*}{$\begin{array}{l}\text { Total \# } \\
\text { Spots }\end{array}$} & \multirow[b]{2}{*}{$\begin{array}{l}\text { \# Spots that } \\
\text { Changed }^{2}\end{array}$} & \multirow[b]{2}{*}{$\begin{array}{l}\text { \# Unique Proteins that } \\
\text { Changed } \\
\text { Cha }\end{array}$} & \multicolumn{3}{|c|}{ Total Spot Volume } & \multicolumn{3}{|c|}{$\mu \mathrm{g}$ Protein/mg Flour } \\
\hline & & & & -PAF & $+\mathrm{PAF}$ & $\begin{array}{c}\% \\
\text { Change }^{4}\end{array}$ & -PAF & $+\mathrm{PAF}$ & $\begin{array}{c}\% \\
\text { Change }\end{array}$ \\
\hline HMW-GS & 40 & 16 & 5 & 12.87 & 17.11 & $32.9^{*}$ & 9.01 & 23.96 & 165.9 \\
\hline LMW-GS $S^{5}$ & 29 & 16 & 3 & 21.11 & 17.93 & $-15.1^{*}$ & 14.78 & 25.11 & 68.9 \\
\hline Alpha-gliadins ${ }^{6}$ & 22 & 8 & 6 & 15.58 & 20.41 & $31.0^{*}$ & 10.90 & 28.56 & 162.1 \\
\hline Gamma-gliadins $^{6}$ & 16 & 7 & 1 & 12.82 & 12.10 & -5.6 & 8.98 & 16.95 & 87.8 \\
\hline Omega-gliadins ${ }^{6}$ & 15 & 13 & 4 & 4.28 & 10.44 & $143.9^{*}$ & 3.00 & 14.62 & 387.8 \\
\hline Gliadin mixed spots ${ }^{6,7}$ & 5 & 2 & $\mathrm{n} / \mathrm{a}$ & 2.12 & 2.56 & 20.3 & 1.49 & 3.58 & 140.7 \\
\hline Globulins & 10 & 5 & 2 & 0.54 & 0.38 & -30.4 & 0.38 & 0.53 & 39.2 \\
\hline Farinins & 8 & 6 & 3 & 2.44 & 0.91 & $-62.9^{*}$ & 1.71 & 1.27 & -25.7 \\
\hline Purinins & 6 & 6 & 3 & 1.50 & 0.82 & $-45.1^{*}$ & 1.05 & 1.15 & 9.9 \\
\hline Triticins & 7 & 1 & 0 & 1.35 & 1.50 & 10.9 & 0.95 & 2.10 & 121.9 \\
\hline GSPs and puroindolines & 4 & 2 & 1 & 0.64 & 0.33 & $-49.0^{*}$ & 0.45 & 0.46 & 2.0 \\
\hline Serpins & 14 & 7 & 5 & 1.15 & 1.58 & $37.4^{*}$ & 0.81 & 2.22 & 174.8 \\
\hline $\begin{array}{l}\text { Amylase/protease } \\
\text { inhibitors }\end{array}$ & 19 & 19 & 13 & 9.55 & 4.09 & $-57.2^{*}$ & 6.69 & 5.73 & -14.3 \\
\hline Other inhibitors & 2 & 0 & 0 & 0.34 & 0.26 & -24.2 & 0.24 & 0.37 & 51.6 \\
\hline Beta-amylase & 6 & 2 & 1 & 0.66 & 0.50 & $-25.0^{*}$ & 0.46 & 0.70 & 49.9 \\
\hline Other enzymes & 23 & 6 & 4 & 2.13 & 1.52 & $-28.8^{*}$ & 1.49 & 2.13 & 42.5 \\
\hline Other miscellaneous & 5 & 3 & 3 & 0.55 & 0.34 & -38.9 & 0.38 & 0.47 & 22.2 \\
\hline No ID & 142 & 36 & $\mathrm{n} / \mathrm{a}$ & 7.28 & 4.95 & $-58.3^{*}$ & 5.10 & 6.94 & 36.1 \\
\hline
\end{tabular}

${ }^{1}$ Total protein was $70 \mu \mathrm{g} / \mathrm{mg}$ flour for $-\mathrm{PAF}$ and $140 \mu \mathrm{g} / \mathrm{mg}$ flour for $+\mathrm{PAF}$; protein amount was calculated as (spot volume)*(total $\mu \mathrm{g} / \mathrm{mg}$ flour)/100.

2 Significant change, $\mathrm{p}<0.02$.

${ }^{3} \mathrm{n} / \mathrm{a}$ indicates not applicable.

$4 *$ indicates that overall change with PAF is significant $(p<0.02)$.

${ }^{5}$ LMW-GSs include only those with classic LMW-GS sequences.

${ }^{6}$ Gliadins include those with odd numbers of Cys that might be incorporated into the glutenin polymer.

${ }^{7}$ Spot contained a mixture of different proteins, but no one sequence was predominant. 
protein content doubled from 70 to $140 \mu \mathrm{g} / \mathrm{mg}$ flour with PAF. Thus, even those proteins that showed no change in SV doubled in amount per unit of flour. Such changes in amount as well as proportion may have significant effects on flour quality. Changes in absolute amounts of each protein type also provide insights into the responses of genes within the different classes. When the spot volume data was converted to absolute protein amounts, it is clear that there was an increase in the absolute amount of protein in most classes (Table 5). Exceptions were the farinins that decreased $26 \%$ in absolute amount, the alpha-amylase/protease inhibitors that decreased $14 \%$ and the puroindolines that showed relatively little change. The degree of change in the different protein classes seemed to be related to the proportions of S-containing amino acids Cys and Met in the mature proteins from each class (Figure 2). The content of the $\mathrm{S}$-containing amino acids ranged from $0 \%$ for most omega-gliadins to $12.3 \%$ for an alpha-amylase inhibitor sequence (Additional file 4). The biggest increase with PAF was for the low S omega-gliadins ( $0 \%$ to $0.6 \%$ Cys plus Met). There were moderate increases for the low-tomedium S serpins (3.2\% Cys plus Met), the low S HMWGSs ( $0.9 \%$ to $1.7 \%$ Cys plus Met), the low-to-medium S alpha-gliadins (2.4\% to $3.1 \%$ Cys plus Met), and triticins (2.5\% Cys plus Met). There were lesser increases for gamma-gliadins (3.6\% to $5.3 \%$ Cys plus Met), LMW-GS (3.7\% to $5.1 \%$ Cys plus Met), and beta-amylase (3.5 to $4.1 \%$ Cys plus Met). The high S purinins (6.5\% to $6.6 \%$ Cys plus Met) showed relatively little change, high $\mathrm{S}$ alpha-amylase/protease inhibitors (9.2\% to $12.3 \%$ Cys plus Met) decreased slightly and high $\mathrm{S}$ farinins (9.8 to $11.2 \%$ Cys plus Met) decreased. There was not a clear relationship between absolute protein amount and Gln plus Pro or Lys content, although Gln plus Pro was highest for those proteins with the lowest amount of Cys plus Met.

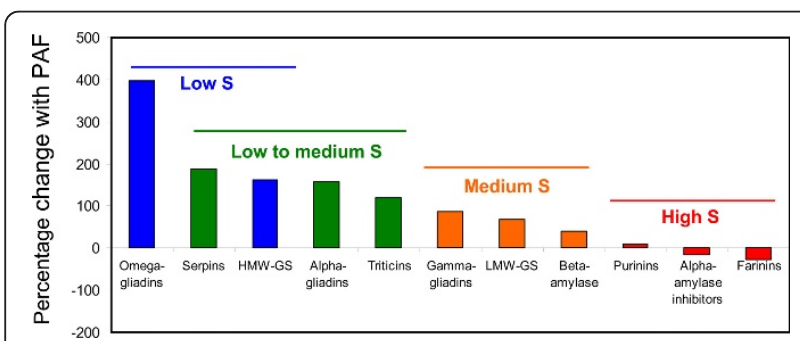

Figure 2 Percentage change in absolute protein amount for protein types with different contents of Cys plus Met. The content of S-containing amino acids was determined for each protein type (Additional file 4). Proteins containing low S are indicated in blue, low to medium $\mathrm{S}$ in green, medium $\mathrm{S}$ in orange and high $\mathrm{S}$ in red.

\section{Discussion}

A 2-DE approach was used to quantify the proportions of individual proteins in flour from grain produced with and without PAF. The study defines the effects of PAF more precisely than prior studies in terms of specific proteins and protein classes and forms a baseline for other 2-DE studies that explore the effects of environmental variables on flour protein composition. The application of PAF significantly increased flour protein content and substantially altered flour protein composition, both of which can impact flour functional properties and quality. More than one third of the total number of individual proteins identified in wheat flour by Dupont et al [28] showed significant changes in SV with PAF. There was an increase in the proportion of HMW-GS and decrease in the proportion of LMW-GS in the flour with PAF and an increase in ratio of HMW-GS to LMW-GS. The proportion of the two types of glutenin subunits in flour is thought to be an important indicator of flour quality because it can affect the nature of large glutenin polymers that confer elasticity to dough made from wheat flour. The ratio of gliadins to glutenins also increased with PAF, due in part to increased proportions of omega- and alpha-gliadins. The gliadins are thought to confer extensibility to dough made from wheat flour, but the roles of specific types of gliadins in flour quality have not been well defined. The data further demonstrated that alpha-gliadins from the Gli-D2 locus containing multiple celiac epitopes and those from the Gli-B2 locus that do not contain celiac epitopes increased to similar degrees. Certain alpha-, gamma- and omegagliadins from Butte 86 also contain odd numbers of Cys residues and are likely to be incorporated into the glutenin polymer [29,30,32]. Of those gliadins with an odd number of Cys, only the omega-gliadins changed in response to PAF.

The work demonstrates that it is possible to use one flour extract to distinguish among highly similar gluten proteins while also quantifying minor flour protein components such as serpins, triticins, farinins, purinins, alphaamylase/protease inhibitors, globulins, puroindolines and enzymes. Serpins increased in proportion with PAF while the farinins, purinins, puroindolines and amylase/protease inhibitors decreased. There was little change in the proportions of triticins and globulins and only a handful of enzymes decreased with PAF. These included two enzymes involved in glucose degradation (beta-amylase and glucose and ribitol dehydrogenase), one involved in glycolysis (triose phosphate isomerase) and one involved in defense (chitinase). Our results are more detailed and precise but are in general agreement with previous studies that distinguished among protein types based on protein fractionation, banding patterns in SDS-PAGE and retention times in RP-HPLC. Most studies separated glutenin, 
gliadin and albumin/globulin or amphiphilic fractions before quantifying them, as it has been difficult to distinguish among these proteins in total flour extracts. However, protein fractionation introduces a trade-off between the purity of each fraction and the amount of protein recovered. Also, a single protein may partition into more than one fraction, and environmental treatments may alter partitioning of proteins among fractions. In contrast, the present study measured the effects of PAF on individual, genetically identifiable proteins without subjecting them to fractionation and thereby provides a valuable overview of the effect of PAF on the major components of the flour.

It is notable that a number of the proteins that changed in proportion with PAF are likely food allergens. Proteins designated as food allergens in the Allergome database [33] that increased in proportion with PAF include the Gli-B3 omega-gliadins (also referred to as the omega-5 gliadins) and the serpins while those that decreased include the defense proteins LTP, chitinase, the alphaamylase inhibitor WTAI-CM3, and thaumatin-like protein. Globulin-2 also has substantial similarity to known food allergens in other plants [34]. Thus, the application of PAF altered the allergenic potential of the flour. In a previous study of developing endosperm from Butte 86, some of the same proteins also changed in proportion in response to high temperatures when plants were supplied with PAF [35]. Interestingly, LTP, chitinase and globulin-2 increased in proportion with high temperature while the proportions of several serpins decreased. These studies illustrate the complex regulation of genes for different wheat flour proteins and highlight the importance of considering effects of the fertilizer regimen in all experiments.

When considered in terms of absolute protein amounts, it is clear that the $\mu \mathrm{g}$ protein per mg flour increased for all gluten proteins as well as for many of the other protein classes. The gliadins and glutenins have a high content of Gln and Pro and serve as efficient reservoirs for storing seed N. As the N-supply increased, the synthesis of gliadins and glutenins increased, particularly ones that were low in S. This is consistent with the observed increase in the ratio of $\mathrm{N}$ to $\mathrm{S}$ in the flour. The response of the farinins to PAF was very different from that of the major gluten proteins. The farinins have moderately high levels of Gln and Pro (31-35\%) and structural similarities to the major wheat gluten proteins. Yet their absolute amounts did not increase with PAF. Instead, their response to PAF was similar to that of the high $\mathrm{S}$ alpha-amylase/protease inhibitors.

The mechanisms by which wheat flour proteins respond to PAF are undoubtedly complex. Overall, it appeared that the response to PAF was related to the $S$ content of the proteins with low $\mathrm{S}$ proteins showing the greatest increase with PAF. However, individual proteins within each class were accumulated to different levels, suggesting different basal levels of expression of the corresponding genes. Additionally, there was a differential response to PAF among individual proteins within certain classes, most notably the alpha-gliadins and LMW-GS. For the omega-gliadins, changes in protein levels are in accord with the results of transcript studies in Butte 86 [16,32]. In previous studies, PAF did not affect the temporal pattern of transcript accumulation but resulted in increased transcript levels for omegagliadins detected by hybridization analysis and by quantitative reverse transcription polymerase chain reaction (qRT-PCR) along with increased rates of omega-gliadin protein accumulation $[15,16]$. This is in agreement with the large increases in omega-gliadin protein reported here. The same qRT-PCR study showed that PAF had little effect on transcript levels of a gamma-gliadin gene [32]. Thus far, transcript levels of HMW-GS, LMW-GS and alpha-gliadins in Butte 86 have been assessed only by hybridization analysis [16]. Further studies are needed to examine the effects of PAF on the expression of individual gluten protein genes during wheat grain development and to address the relationships between promoter structures for these genes, differences in basal levels of gene expression and the differing effects of $\mathrm{N}$ on protein accumulation.

While 2-DE is a powerful method for evaluating changes in flour protein profiles in response to specific treatments, the data is complex and needs to be considered on several levels. Frequently, 2-DE studies report changes in individual spots that are subsequently identified by MS/MS. This approach reveals only part of the overall picture. Recent studies indicate that the same protein sequence can be distributed among several different 2-DE spots [28,36-39] and that all spots associated with a unique protein sequence may not show the same response. While it is not known whether the origin of these multiple spots is biologically significant or due to extraction and/or analytical techniques [28], it nonetheless is important to consider each change in the context of the proteome being analyzed. In this study, individual spots associated with 77 protein sequences showed significant changes in SV with PAF. However, when the volumes for all spots containing the same unique proteins were summed, changes in only 54 distinct protein sequences were significant. Additionally, when MS/MS methods are optimized to generate large numbers of peptides for each spot as was done in the Dupont et al. [28] study, it is apparent that single 2-DE spots often contain more than one protein sequence. In most cases, the majority of peptides obtained by MS/MS from a spot could be assigned to a single sequence that was designated as the predominant protein in the spot. For example, 45 peptides were identified by MS/MS for spot 524 [28]. Thirty-two were assigned to alpha-gliadin $\mathrm{Bu}-12$ resulting in $80 \% \mathrm{MS} /$ MS coverage, while the remaining nine peptides were 
distributed among three other alpha-gliadin sequences. It is certainly possible that the changes observed in this spot with PAF are due to changes in the levels of minor proteins in the spot rather than to the predominant protein. MS/ MS analysis of equivalent spots from both treatments could help to resolve this issue. Finally, it is not always possible to identify all of the protein spots that respond to a treatment. In this study, we were unable to obtain valid identifications for 36 spots that changed significantly with PAF, all of which represented minor components of the flour. The failure to identify these proteins may be because they were of very low abundance. It is also possible that the proteins did not cleave well with the proteases used for MS/MS identification, the peptides were not detected by the mass spectrometer or the corresponding protein sequences were not present in the database searched with MS/MS data. Further studies of fractionated flour proteins may complement this study and identify additional minor components that may be of interest. Despite limitations of the 2-DE approach, this study provides new insight into the effects of PAF on individual flour proteins that are important for flour quality and allergenic potential.

\section{Conclusions}

Millers and bakers encourage scientists to produce cultivars with increased stability of flour quality across years and growth environments. However, to select targets for breeding programs or biotechnology efforts it is important to first identify the genes and proteins that contribute to variability in quality. The current study used quantitative 2-DE to address the effects of PAF on the entire array of abundant flour proteins. The results indicate that omega-gliadins are very sensitive to PAF and could be a major source of environmental variability. HMW-GSs, serpins, certain alpha-gliadins and LMWGSs also appear to contribute to this variability. The study is essential for predicting the effects of agronomic inputs on flour composition and establishes the foundation for future work aimed at deciphering the complex effects of temperature and drought on the wheat flour proteome.

\section{Methods}

\section{Plant materials}

Plants of the US hard red spring wheat Triticum aestivum 'Butte $86^{\prime}$ were grown in a climate-controlled greenhouse with $16 \mathrm{hr}$ days and $8 \mathrm{hr}$ nights at $24^{\circ} \mathrm{C}$ maximum daytime and $17^{\circ} \mathrm{C}$ minimum night-time temperatures $[1,28]$. Prior to anthesis, plants were watered by drip irrigation with 0.6 g.l ${ }^{-1}$ Plantex fertilizer (NPK, 20:20:20), at approximately $0.1 \mathrm{~g}$ each of $\mathrm{N}, \mathrm{P}$ and $\mathrm{K}$ per pot per day. Plants were grown in 36 pots of $25 \mathrm{~cm}$ diameter at a density of seven plants per pot. At anthesis, pots were divided into six groups. Three sets of pots were flushed with water to remove remaining NPK and subsequently were hand-watered without fertilizer. The other three sets of pots received drip irrigation with NPK fertilization, at approximately $0.3 \mathrm{~g}$ each of $\mathrm{N}, \mathrm{P}$ and $\mathrm{K}$ per pot per day. Sets with and without fertilizer were alternated spatially in the greenhouse, and pots within a set were rotated weekly. Pots were weighed daily and water added to maintain the pots at $80 \%$ of water capacity. Grain was harvested at maturity and samples were milled to white flour with a Brabender Quadrumat Junior (South Hackensack, NJ) at the Hard Winter Wheat Quality Laboratory (US Department of Agriculture, Agricultural Research Service, Manhattan, KS) and tested for mixing and baking quality as previously described [15]. Subsequently, flour was stored at $-80^{\circ} \mathrm{C}$. Flour N, C and S were determined by combustion analysis of $35 \mathrm{mg}$ samples, in triplicate, using an Elementar Vario Macro Elemental Analyzer (Hanau, Germany) in CNS mode with a sulfadiazine standard. Protein was calculated as 5.7 times N.

\section{2-DE of total flour proteins}

Three separate samples of flour from each biological replicate were extracted and analyzed by 2 -DE (18 gels total) as described in detail previously [28,40,41]. Briefly, total flour protein was extracted with SDS under reducing conditions, precipitated with acetone and protein amount determined by the method of Lowry et al. [42]. Dried protein was solubilized in urea buffer consisting of $9 \mathrm{M}$ urea, $4 \%$ NP-40, 1\% DTT and 2\% ampholytes at a concentration of $3 \mu \mathrm{g} / \mu \mathrm{l}$, then $18 \mu \mathrm{g}$ was loaded onto each IEF gel, focused, and IEF gels were frozen at $-70^{\circ} \mathrm{C}$. Proteins were separated in the second dimension by SDS gel electrophoresis using Novex NuPage 4-12\% acrylamide Bis-Tris gels with MES/ SDS running buffer (Invitrogen Corporation, Carlsbad, CA). Gels were stained with Coomasie G-250 (Sigma, St. Louis, MO), destained in water for $2 \mathrm{~h}$ and stored at $4^{\circ} \mathrm{C}$ in $20 \%$ ammonium sulfate. Gels were scanned and spots were matched between gels, quantified and normalized using computer software (Progenesis PG240 v 2006, Nonlinear Dynamics, Newcastle upon Tyne, UK) as described in detail [28]. All proteins were identified previously by MS/MS [28]. Spot volumes of identified protein spots were also reported in [28]. Visual inspection of identified spots matched between gels by computer software detected no matching errors.

\section{Statistical analysis}

The experimental plan included two treatments and three biological replicas, obtained from the three sets of six individual pots for each treatment. For each of the resulting six flour samples, 2-DE was performed in triplicate. The 2-DE analysis software computed the SV for each spot as the average of the three replicate gels. These average SVs for the three biological replicates and two 
treatments were then subjected to analysis of variance for each spot with SAS software (SAS Institute Inc. 2009. SAS OnlineDoc ${ }^{\circledR}$ 9.2. Cary, NC: SAS Institute Inc.). Means and standard deviations for all proteins were similar among biological replicates. Probabilities from an F-test comparing means of the two treatments were calculated, both assuming that the variances were similar enough to be pooled for both treatments (4 error degrees of freedom) or differed enough between the treatments that pooling would not be appropriate (2 error degrees of freedom). An F-test was used comparing the two error terms to determine which mean comparison test was more appropriate. A Bonferroni adjustment to the $\mathrm{F}$ probability was also made to account for the increased likelihood of chance significance in a large set of tests. Similar calculations were made for the sums of the SVs for specific protein sequences and specific protein types, in which the average SVs for each spot for a biological replica were summed and then these sums for the three biological replicas were used in computing the analysis of variance for each protein sequence or protein type. Appropriate calculations are shown in Additional files 1, 2 and 3; generally the calculation using the simplest assumption was used for tables in the main document.

The absolute amount of each protein per mg of flour was estimated by multiplying SV by total protein per mg of flour. Proportions of Cys, Met, Lys, Pro and Gln were calculated as the percentage of total amino acids in the mature proteins using published sequences from Butte 86 [28-30] or sequences from NCBI. Because most omega-gliadin sequences are incomplete, this information was determined from amino acid analysis of purified proteins [43].

\section{Additional material}

Additional file 1: Statistical analysis for all individual 2-DE spots

Additional file 2: Statistical analysis for summed spot volumes for each unique protein sequence.

Additional file 3: Statistical analysis for summed spot volumes for each protein class.

Additional file 4: Proportions of key amino acids in flour protein types based on the sequences of the mature proteins.

\begin{abstract}
Abbreviations
2-DE: 2-dimensional gel electrophoresis; HMW-GS: high molecular weight glutenin subunit; LMW-GS: low molecular weight glutenin subunit; MS/MS: tandem mass spectrometry; N: nitrogen; NPK: nitrogen, phosphorus, potassium 1:1:1 fertilizer; PAF: post-anthesis fertilization; RP-HPLC: reverse phase-high pressure liquid chromatography; S: sulfur; SDS-PAGE: SDS polyacrylamide gel electrophoresis; SV: normalized spot volume.
\end{abstract}

\section{Acknowledgements}

The authors thank Dr. Donald Kasarda for many discussions about the results, and Dr. Ann Blechl and Dr. Roger Thilmony for careful review of the manuscript and useful suggestions about data presentation. The authors also thank the Hard Red Wheat Quality Research Unit, USDA, Manhattan KS for milling and baking quality analyses. This research was funded by USDA Agricultural Research Service CRIS Project 5325-43000-026-00D. Mention of a specific product name by the United States Department of Agriculture does not constitute an endorsement and does not imply a recommendation over other suitable products. USDA is an equal opportunity provider and employer.

\section{Authors' contributions}

FD and SA designed the study, analyzed and interpreted the data and drafted the manuscript; CT carried out the quantitative 2-DE gel analysis; $\mathrm{WH}$ participated in the 2-DE gel analysis; LW advised on experimental design and performed statistical analysis and interpretation; W provided the original MS/MS analysis that was essential to the project. All authors read and approved the manuscript.

\section{Competing interests}

The authors declare that they have no competing interests.

Received: 19 April 2011 Accepted: 4 August 2011

Published: 4 August 2011

\section{References}

1. Altenbach SB, Dupont F, Kothari K, Chan R, Johnson EL, Lieu D: Temperature, water and fertilizer influence the timing of key events during grain development in a US spring wheat. J Cereal Sci 2003, 37:9-20.

2. Barraclough PB, Howarth JR, Jones J, Lopez-Bellido R, Parmar S, Shepherd CE, Hawkesford MJ: Nitrogen efficiency of wheat: genotypic and environmental variation and prospects for improvement. Eur J Agron 2010, 33:1-11.

3. Barneix A: Physiology and biochemistry of source-regulated protein accumulation in the wheat grain. J Plant Physiol 2007, 164:581-590.

4. Bogard M, Allard V, Brancourt-Hulmel M, Heumez E, Machet JM, Jeuffroy MH, Gate P, Martre P, Le Gouis J: Deviation from the grain protein concentration-grain yield negative relationship is highly correlated to post-anthesis N uptake in winter wheat. J Expt Botany 2010, 61:4303-4312.

5. Fowler DB: Crop nitrogen demand and grain protein concentration of spring and winter wheat. Agron J 2003, 95:260-265.

6. Godfrey D, Hawkesford MJ, Powers SJ, Millar S, Shewry PR: Effects of crop nutrition on wheat grain composition and end use quality. J Agric Food Chem 2010, 58:3012-3021.

7. Weegels PL, Hamer RJ, Schofield JD: Critical review: functional properties of wheat glutenin. J Cereal Sci 1996, 23:1-18.

8. Baker DA, Young DL, Huggins DR, Pan WL: Nitrogen management. Economically optimal nitrogen fertilization for yield and protein in hard red spring wheat. Wheat Agron J 2004, 96:116-123, 2004.

9. Jenner CF, Ugalde TD, Aspinall D: The physiology of starch and protein deposition in the endosperm of wheat. Austr J Plant Physiol 1991 18:211-226.

10. Simmonds NW: The relation between yield and protein in cereal grain. J Sci Food Agric 1995, 67:309-315.

11. Randall PJ, Freney JR, Smith CJ, Moss HJ, Wrigley CW, Galbally IE: Effect of additions of nitrogen and sulfur to irrigated wheat at heading on grain yield, composition and milling and baking quality. Aust J Exp Agric 1990, 30:95-101.

12. Martre $P$, Jamieson PD, Semenov MA, Zyskowski RF, Porter JR, Triboi E: Modelling protein content and composition in relation to crop nitrogen dynamics for wheat. Eur J Agron 2006, 25:138-154.

13. Shewry PR, Halford NG, Lafiandra D: Genetics of wheat gluten proteins. Adv Genet 2003, 49:111-184.

14. Osborne TB: The vegetable proteins. Longmans Green and Company, London; 1909.

15. Dupont FM, Hurkman WJ, Vensel WH, Tanaka C, Kothari KM, Chung OK, Altenbach SB: Protein accumulation and composition in wheat grains: effects of mineral nutrients and high temperature. Eur J Agron 2006, 25:96-107.

16. Dupont FM, Hurkman WJ, Vensel WH, Chan R, Lopez R, Tanaka CK, Altenbach SB: Differential accumulation of sulfur-rich and sulfur-poor wheat flour proteins is affected by temperature and mineral nutrition during grain development. J Cereal Sci 2006, 44:101-112. 
17. Martre P, Porter JR, Jamieson PD, Triboi E: Modeling grain nitrogen accumulation and protein composition to understand the sink/source regulations of nitrogen remobilization for wheat. Plant Physiol 2003, 133:1959-1967.

18. Wieser $\mathrm{H}$, Seilmeier $\mathrm{W}$ : The influence of nitrogen fertilization on quantities and proportions of different protein types in wheat flour. J Sci Food Agric 1998, 76:49-55.

19. Triboi E, Abad A, Michelena A, Lloveras J, Ollier JL, Daniel C: Environmental effects on the quality of two wheat genotypes: 1. Quantitative and qualitative variation of storage proteins. Eur J Agron 2000, 13:47-64.

20. Wrigley CW, Du Cros DL, Fullington JG, Kasarda DD: Changes in polypeptide composition and grain quality due to sulfur deficiency in wheat. J Cereal Sci 1984, 2:15-24.

21. Wieser $H$, Gutser $R$, Von Tucher $S$ : Influence of sulphur fertilization on quantities and proportions of gluten protein types in wheat flour. J Cereal Sci 2004, 40:239-244.

22. Zhao FJ, Hawkesford MJ, McGrath SP: Sulphur assimilation and effects on yield and quality of wheat. J Cereal Sci 1999, 30:1-17.

23. Zorb C, Steinfurth D, Seling S, Langenkamper G, Koehler P, Wieser H, Lindhauer MG, Muhling KH: Quantitative protein composition and baking quality of winter wheat as affected by late sulfur fertilization. J Agric Food Chem 2009, 57:3877-3885.

24. Grove H, Hollung K, Moldestad A, Faergestad EM, Uhlen AK: Proteome changes in wheat subjected to different nitrogen and sulfur fertilizations. J Agric Food Chem 2009, 57:4250-4258.

25. Zorb C, Grover C, Steinfurth D, Muhling KH: Quantitative proteome analysis of wheat gluten as influenced by $\mathrm{N}$ and $\mathrm{S}$ nutrition. Plant Soil 2010, 327:225-234.

26. Ferranti P, Mamone G, Picariello G, Addeo F: Mass spectrometry analysis of gliadins in celiac disease. J Mass Spectrom 2007, 42:1531-1548.

27. Mamone G, Addeo F, Chianese L, Di Luccia A, De Martino A, Nappo A, Formisano A, De Vivo P, Ferranti P: Characterization of wheat gliadin proteins by combined two-dimensional gel electrophoresis and tandem mass spectrometry. Proteomics 2005, 5:2859-2865.

28. Dupont FM, Vensel WH, Tanaka CK, Hurkman WJ, Altenbach SB: Deciphering the complexities of the wheat flour proteome using quantitative two-dimensional electrophoresis, three proteases and tandem mass spectrometry. Proteome Sci 2011, 9:10.

29. Altenbach SB, Vensel WH, Dupont FM: Analysis of expressed sequence tags from a single wheat cultivar facilitates interpretation of tandem mass spectrometry data and discrimination of gamma gliadin proteins that may play different functional roles in flour. BMC Plant Biol 2010, 10:7.

30. Altenbach SB, Vensel WH, Dupont FM: Integration of transcriptomic and proteomic data from a single wheat cultivar provides new tools for understanding the roles of individual alpha gliadin proteins in flour quality and celiac disease. $J$ Cereal Sci 2010, 52:143-151.

31. Vensel WH, Dupont FM, Sloane S, Altenbach SB: Effect of cleavage enzyme, search algorithm and decoy database on mass spectrometric identification of wheat gluten proteins. Phytochem 2011, 72:1154-1161.

32. Altenbach SB, Kothari KM: Omega gliadin genes expressed in Triticum aestivum cv Butte 86: effects of post-anthesis fertilizer on transcript accumulation during grain development. J Cereal Sci 2007, 46:169-177.

33. Allergome the Platform for Allergen Knowledge. [http://www.allergome. org/].

34. Altenbach SB, Tanaka CK, Hurkman WJ, Vensel WH: Expression of globulin2 , a member of the cupin superfamily of proteins with similarity to know food allergens, is increased under high temperature regimens during wheat grain development. J Cereal Sci 2009, 49:47-54.

35. Hurkman WJ, Vensel WH, Tanaka CK, Whitehand L, Altenbach SB: Effect of high temperature on albumin and globulin accumulation in the endosperm proteome of the developing wheat grain. J Cereal Sci 2009, 49:12-23.

36. Mamone G, De Caro S, Di Luccia A, Addeo F, Ferranti P: Proteomic-based analytical approach for the characterization of glutenin subunits in durum wheat. J Mass Spectrom 2009, 44:1709-1723.

37. Payne PI, Holt LM, Jarvis MG, Jackson EA: Two dimensional fractionation of the endosperm proteins of bread wheat (Triticum aestivum): Biochemical and genetical studies. Cereal Chem 1985, 62:319-326.

38. Dong L, Zhang X, Liu D, Fan H, Sun J, Zhang Z, Qin H, Li B, Hao S, Li Z, Wang D, Zhang A, Ling HQ: New insights into the organization, recombination, expression and functional mechanism of low molecular weight glutenin subunit genes in bread wheat. PLOS One 2010, 5:e13548.

39. Yang F, Jorgensen AD, Li H, Sondergaard I, Finnie C, Svensson B, Jiang D, Wollenweber B, Jacobsen S: Implications of high-temperature events and water deficits on protein profiles in wheat (Triticum aestivum L. cV. Vinjett) grain. Proteomics 2011, 11:1684-1695.

40. Hurkman WJ, Tanaka CK: Extraction of wheat endosperm proteins for proteome analysis. J Chrom B 2007, 849:344-350.

41. Hurkman WJ, Tanaka CK: Improved methods for separation of wheat endosperm proteins and analysis by two-dimensional gel electrophoresis. J Cereal Sci 2004, 40:295-299.

42. Lowry OH, Rosebrough NJ, Farr AL, Randall RJ: Protein measurement with the Folin phenol reagent. J Biol Chem 1951, 193:265-275.

43. DuPont FM, Chan R, Vensel WH, Kasarda DD: Characterization of the 1Btype gliadins from Triticum aestivum cultivar Butte. Cereal Chem 2000, 77:607-614.

doi:10.1186/1477-5956-9-46

Cite this article as: Altenbach et al.: Differential effects of a postanthesis fertilizer regimen on the wheat flour proteome determined by quantitative 2-DE. Proteome Science 2011 9:46.

\section{Submit your next manuscript to BioMed Central and take full advantage of:}

- Convenient online submission

- Thorough peer review

- No space constraints or color figure charges

- Immediate publication on acceptance

- Inclusion in PubMed, CAS, Scopus and Google Scholar

- Research which is freely available for redistribution

Submit your manuscript at www.biomedcentral.com/submit
Ciomed Central 